\begin{tabular}{|c|c|}
\hline Title & $\begin{array}{l}\text { Diverse structures and adsorption properties of quasi-Werner-type copper(II) complexes with flexible and polar axial } \\
\text { bonds }\end{array}$ \\
\hline Author(s) & $\begin{array}{l}\text { Noro, Shin-ichiro; Ohba, Tomonori; Fukuhara, Katsuo; Takahashi, Y ukiko; A kutagawa, Tomoyuki; Nakamura, } \\
\text { Takay oshi }\end{array}$ \\
\hline Citation & $\begin{array}{l}\text { Dalton Transactions, } 40(10), 2268-2274 \\
\text { https://doi.org/10.1039/c0dt01129k }\end{array}$ \\
\hline Issue Date & 2011-03-14 \\
\hline Doc URL & http:/hdl.handle.net/2115/49201 \\
\hline Rights & Dalton Trans., 2011, 40, 2268-2274- Reproduced by permission of The Royal Society of Chemistry (RSC) \\
\hline Type & article (author version) \\
\hline File Information & DT 40-10_2268-2274.pdf \\
\hline
\end{tabular}

Instructions for use 


\title{
Diverse structures and adsorption properties of quasi-Werner-type copper(II) complexes with flexible and polar axial bonds
}

\author{
Shin-ichiro Noro, ${ }^{a, b}$ Tomonori Ohba, ${ }^{c}$ Katsuo Fukuhara, ${ }^{b}$ Yukiko Takahashi, ${ }^{a}$ Tomoyuki Akutagawa ${ }^{d}$ \\ and Takayoshi Nakamura*a,b
}

\author{
Received (in $X X X, X X X)$ Xth $X X X X X X X X X 200 X$, Accepted Xth XXXXXXXXX 200X \\ First published on the web Xth $X X X X X X X X X 200 X$ \\ DOI: $10.1039 / b 000000 x$
}

\begin{abstract}
The quasi-Werner-type copper(II) complex, $\left[\mathrm{Cu}\left(\mathrm{PF}_{6}\right)_{2}(4-\text {-mepy })_{4}\right](\mathbf{1})$, in which 4-mepy is the 4methylpyridine ligand, has flexible and polar axial bonds of $\mathrm{Cu}-\mathrm{PF}_{6}$. Flexibility of the $\mathrm{Cu}-\mathrm{PF}_{6}$ bonds induces diverse and unprecedented guest-inclusion structures, such as $\left\{\left[\mathrm{Cu}\left(\mathrm{PF}_{6}\right)_{2}(4-\right.\right.$

mepy $\left.)_{4}\right]\left[\mathrm{Cu}\left(\mathrm{PF}_{6}\right)\left(4-\right.\right.$ mepy $_{4}$ (acetone) $] \cdot \mathrm{PF}_{6} \bullet$ 4acetone $\}$ ( $\gamma$-1 $\supset 2.5$ acetone $),\left\{\left[\mathrm{Cu}\left(\mathrm{PF}_{6}\right)_{2}(4-\right.\right.$

mepy) $\left.)_{4}\right]\left[\mathrm{Cu}\left(\mathrm{PF}_{6}\right) \text { (4-mepy) }\right)_{4}(2$-butanone) $] \cdot \mathrm{PF}_{6} \cdot 3.5$ (2-butanone) $\}$ ( $\gamma$-1つ2.25(2-butanone)),

$\left\{\left[\mathrm{Cu}\left(\mathrm{PF}_{6}\right)_{2}\left(4-\mathrm{mepy}_{4}\right]\left[\mathrm{Cu}\left(\mathrm{PF}_{6}\right)\left(4-\mathrm{mepy}_{4}\left(\mathrm{H}_{2} \mathrm{O}\right)\right] \cdot \mathrm{PF}_{6} \bullet\right.\right.\right.$ 4benzene $\}\left(\gamma-1 \supset 0.5 \mathrm{H}_{2} \mathrm{O} \cdot 2\right.$ benzene $)$, and

$\left\{\left[\mathrm{Cu}\left(\mathrm{PF}_{6}\right)_{2}(4-\mathrm{mepy})_{4}\right] \cdot 2\right.$ benzene $\}(\gamma-1 \supset 2$ benzene). Exposure of the dense form, $\alpha-\mathbf{1}$, to benzene vapor affords the benzene-inclusion complex $\left\{\left[\mathrm{Cu}\left(\mathrm{PF}_{6}\right)_{2}(4 \text {-mepy })_{4}\right] \cdot 2\right.$ benzene $\}(\gamma$-1 $\supset$ 2benzene), all benzene guests of which are easily removed by vacuum drying, reforming guest-free, dense $\alpha \mathbf{- 1}^{\prime}$ with smaller sized crystals than $\alpha \mathbf{- 1}$. In contrast to $\alpha \mathbf{- 1}$, which shows almost no $\mathrm{CO}_{2}$ adsorption, $\alpha$ $\mathbf{1}^{\prime}$ adsorbs $\mathrm{CO}_{2}$ gas with structural transformations, this being the first example that exhibits adsorption of gas in a dense Werner-type complex and a drastic change in adsorption properties depending on the size of the crystals.
\end{abstract}

\section{Introduction}

Porous materials constructed from metal ions and organic ligands are now of great interest because of the advantages for storage, separation, and catalysis, each of which can be rationally controlled using their characteristics, such as high designability, structural diversity and regularity, and flexibility. There are three types of such porous materials: one is called porous coordination polymers (PCPs) or metalorganic frameworks (MOFs) that have polymeric frameworks with regular pores; ${ }^{1}$ the second is discrete clusters (metalorganic polyhedra (MOPs)) with tailorable internal space; ${ }^{2}$ and the third is formed by the assembly of discrete coordination complexes without internal space via weaker intermolecular interactions (van der Waals, electrostatic, and hydrogen-bonding interactions) than coordination bonds. ${ }^{3-5}$

The Werner-type complex formulated as $\left[\mathrm{Ni}(\mathrm{NCS})_{2}(4-\right.$ mepy) ${ }_{4}$ ] (4-mepy = 4-methylpyridine) and its derivatives are well known as examples of the third porous materials type defined above, their preparation and guest inclusion ability first being reported in $1957 .^{3 a}$ Among them, [Ni(NCS) $)_{2}(4-$ mepy $)_{4}$ ] has been thoroughly studied because of the interesting guest-inclusion properties derived from pseudopolymorphism, such as a dense $\alpha$-form, and guestincluding $\beta$ - and $\gamma$-forms. In particular, this complex easily affords an empty $\beta$-form that adsorbs several gases with type I isotherms. In this complex, the coordination environment around the $\mathrm{Ni}^{\mathrm{II}}$ ion always remains unchanged, irrespective of its assembly state. Then, another complex, $\left[\mathrm{CuL}_{2}\right](\mathrm{L}=$ $\left.\left\{\mathrm{CF}_{3} \mathrm{COCHCOC}\left(\mathrm{CH}_{3}\right)_{2} \mathrm{OCH}_{3}\right\}^{-}\right)$, ${ }^{4 a}$ was found that also gives three pseudopolymorphs: a dense $\alpha$-form, a porous $\beta$-form, and one other. The $\mathrm{Cu}^{\mathrm{II}}$ atom in this complex has square- planar coordination from two chelating ligands having asymmetric substituents. The $\alpha$-form contains both cis and trans $\left[\mathrm{CuL}_{2}\right]$ units, whereas the $\beta$-form contains only trans units. Each unit in both forms is linked by weak coordination interactions between the $\mathrm{Cu}^{\mathrm{II}}$ ions and the oxygen atoms of methoxy groups, forming polymeric frameworks. Further, a new phase, neither the $\alpha$ - nor $\beta$-form, is formed by exposure to $\mathrm{MeOH}$ or $\mathrm{EtOH}$ vapor, in which the oxygen atoms of $\mathrm{MeOH}$ or EtOH occupy the $\mathrm{Cu}^{\mathrm{II}}$ axial sites, resulting in discrete coordination complexes. ${ }^{4 \mathrm{c}}$ Such a characteristic arises from weak axial $\mathrm{Cu}^{\mathrm{II}}$ bonds. Here, we define these third porous materials as porous assemblies of coordination complex (PACs). Although there have been a large number of reports on PCPs and MOPs with intriguing porous functionalities to date, corresponding examples of PACs are much less common; the studies of PACs have been mainly based on structural chemistry.

Based on the excellent pioneering work on PACs, we focused on a new PAC, $\left[\mathrm{Cu}\left(\mathrm{PF}_{6}\right)_{2}(4-\text { mepy })_{4}\right](\mathbf{1})$, which is a quasi-Werner-type metal complex. Recently, we have found that the porous $\mathrm{Cu}^{\mathrm{II}}$ coordination polymer (PCCP) $\left[\mathrm{Cu}\left(\mathrm{PF}_{6}\right)_{2}(\text { bpetha })_{2}\right]_{n}$ (bpetha $=1$,2-bis(4-pyridyl)ethane) with flexible and polar $\mathrm{Cu}-\mathrm{PF}_{6}$ bonds has interesting guestrecognition abilities. ${ }^{6}$ This $\mathrm{PCCP}$ has polar $\mathrm{Cu}-\mathrm{PF}_{6}$ units in the framework and therefore selectively adsorbs $\mathrm{CO}_{2}$ and $\mathrm{C}_{2} \mathrm{H}_{2}$ gases with Lewis-acid properties via electron donoracceptor interactions. ${ }^{7 a}$ On the other hand, when this PCCP is exposed to Lewis-base guests with sterically less-crowded coordinated atoms, the weakly coordinated $\mathrm{PF}_{6}{ }^{-}$anions are easily released from the axial sites and Lewis-base guests attach to these sites instead. This characteristic enables the PCCP to selectively separate large molecules from Lewis-base mixtures by using the differences in molecular shape. ${ }^{7 \mathrm{~b}}$ These 
results clearly indicate that the flexible and polar $\mathrm{Cu}-\mathrm{PF}_{6}$ units are useful for the construction of porous materials with multiguest-recognition properties. Introducing the $\mathrm{Cu}-\mathrm{PF}_{6}$ units to the Werner-type complexes, we could obtain unprecedented PACs that show a variety of structures depending on the type of included guests and selective guest adsorption properties.

The synthesis and crystallographic characterization of the dense $\alpha$-form $(\alpha-1)$ have been previously reported. ${ }^{7 \mathrm{a}, 8}$ Here, we determined the crystal structures of four $\gamma$-type inclusion complexes, $\left\{\left[\mathrm{Cu}\left(\mathrm{PF}_{6}\right)_{2}\left(4-\mathrm{mepy}_{4}\right]\left[\mathrm{Cu}\left(\mathrm{PF}_{6}\right)(4-\right.\right.\right.$ mepy $)_{4}$ (acetone) $] \cdot \mathrm{PF}_{6} \bullet 4$ acetone $\}$ $(\gamma-1 \supset 2.5$ acetone $)$, $\left\{\left[\mathrm{Cu}\left(\mathrm{PF}_{6}\right)_{2}(4-\mathrm{mepy})_{4}\right]\left[\mathrm{Cu}\left(\mathrm{PF}_{6}\right)(4-\text {-mepy })_{4}(2-\right.\right.$

butanone $)] \cdot \mathrm{PF}_{6} \bullet 3.5(2$-butanone $\left.)\right\} \quad(\gamma$-1 $\supset 2.25(2$-butanone $))$, $\left\{\left[\mathrm{Cu}\left(\mathrm{PF}_{6}\right)_{2}\left(4-\mathrm{mepy}_{4}\right]\left[\mathrm{Cu}\left(\mathrm{PF}_{6}\right)(4-\right.\right.\right.$

mepy $\left.)_{4}\left(\mathrm{H}_{2} \mathrm{O}\right)\right] \cdot \mathrm{PF}_{6} \bullet$ 4benzene $\} \quad\left(\gamma-\mathbf{1} \supset 0.5 \mathrm{H}_{2} \mathrm{O} \cdot 2\right.$ benzene $)$, and $\left\{\left[\mathrm{Cu}\left(\mathrm{PF}_{6}\right)_{2}(4 \text {-mepy })_{4}\right] \cdot 2\right.$ benzene $\} \quad(\gamma$-1 $\supset$ 2benzene $)$, obtained by recrystallization of $\alpha-1$ in the presence of guest molecules. The guest-including $\gamma$-forms $(\gamma$-1 $\supset 2$.5acetone, $\gamma$-1 $\supset 2.25(2-$ butanone), and $\gamma-1 \supset 0.5 \mathrm{H}_{2} \mathrm{O} \cdot 2$ benzene) trapped Lewis-base guests in the uncommon mode, which has never been observed in traditional Werner-type complexes. We also examined the gas adsorption properties of the dense $\alpha$-forms, and succeeded in achieving the adsorption of $\mathrm{CO}_{2}$ gas with structural transformations in its form.

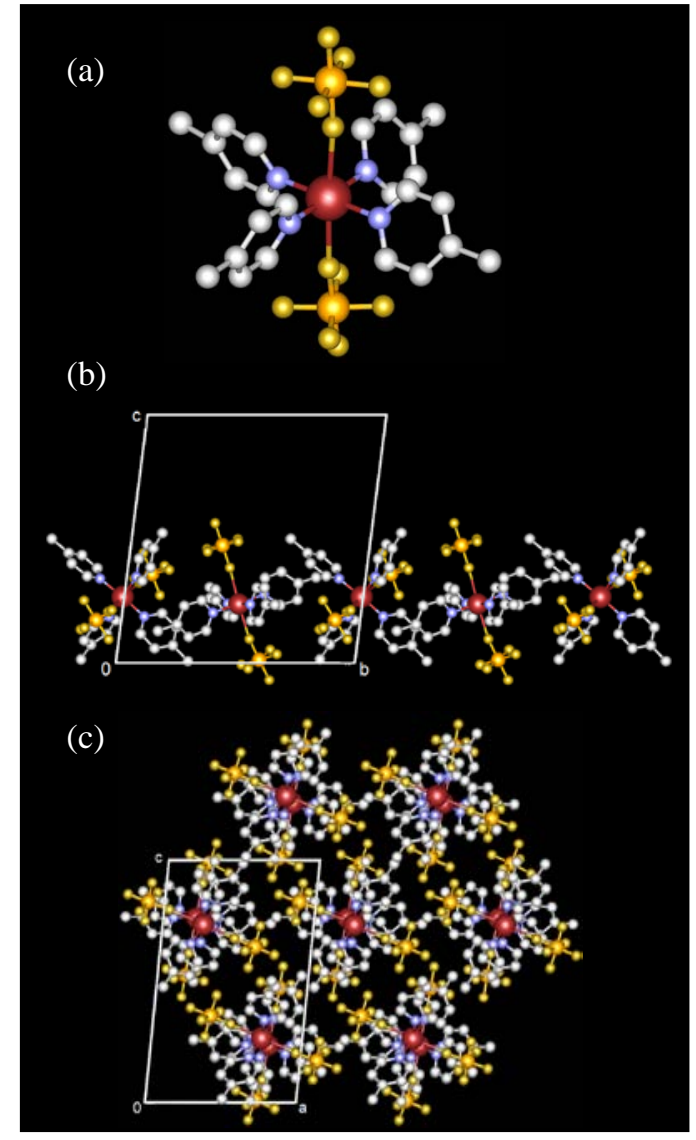

Fig. 1 Crystal structure of $\alpha-1$ : (a) the molecular structure, (b) the chain arrangement in the projection along the $a$-axis, and (c) the packing view in the projection along the $b$-axis. The hydrogen atoms are omitted for clarity. The red, blue, gray, gold, and orange colors represent copper, nitrogen, carbon, fluorine, and phosphorus, respectively.

\section{Results and discussion}

\section{Crystal structures}

The synthesis and characterization of $\alpha-1$ were performed by Morrison and Thompson about 30 years ago. ${ }^{8}$ Recently, we have succeeded in the single-crystal X-ray diffraction analysis of $\alpha-1 .^{7 a}$ The crystal structure of $\alpha-1$ has been briefly reported in our previous literature. Here, we elucidate its structure in more detail. In the crystal, there are two crystallographically independent $\mathrm{Cu}^{\mathrm{II}}$ complexes (I and II), both of which have similar coordination environments. The $\mathrm{Cu}^{\mathrm{II}}$ ion has an elongated octahedral environment with four 4-mepy nitrogen atoms in the equatorial plane, and two fluorine atoms of the $\mathrm{PF}_{6}{ }^{-}$anions at the axial sites (Fig. 1a). Each $\mathrm{Cu}^{\mathrm{II}}$ complex adopts a propeller-type conformation. The $\mathrm{Cu}-\mathrm{F}$ bond distances (2.586(2) and 2.528(2) $\AA$ for complex I, and 2.478(2) and 2.629(2) $\AA$ for complex II) are considerably longer than the $\mathrm{Cu}-\mathrm{N}$ bond distances (2.002-2.024 $\AA$ ), indicative of a Jahn-Teller effect. The $\mathrm{Ni}^{\mathrm{II}}$ analogue has been reported, ${ }^{9}$ in which the $\mathrm{Ni}^{\mathrm{II}}$ ion has a nearly square-planar environment and the $\mathrm{Ni}-\mathrm{F}$ bond distance is 3.031(8) $\AA$, only marginally less than the estimated sum of the van der Waals radii (3.10 $\AA$ ), but considerably more than the $\mathrm{Cu}-\mathrm{F}$ bond distances in $\alpha-\mathbf{1}$. Therefore, the $\mathrm{PF}_{6}{ }^{-}$anions of $\alpha-\mathbf{1}$ interact with the $\mathrm{Cu}^{\mathrm{II}}$ ions more strongly than those of the $\mathrm{Ni}^{\mathrm{II}}$ analogue. Generally, $\mathrm{Ni}^{\mathrm{II}}$ complexes show an octahedral or square-planar coordination environment. Having a weak Lewis-base ability, ${ }^{10}$ the $\mathrm{PF}_{6}{ }^{-}$anion is hardly coordinated to a $\mathrm{Ni}^{\mathrm{II}}$ ion, resulting in a nearly square-planar coordination environment. The difference in coordination states of the $\mathrm{PF}_{6}{ }^{-}$ anions between $\alpha-\mathbf{1}$ and the $\mathrm{Ni}^{\mathrm{II}}$ analogue can also be confirmed by a comparison of $\mathrm{P}-\mathrm{F}$ bond distances. In the case of $\alpha-1$, the $\mathrm{P}-\mathrm{F}$ bond distances with weakly coordinated $\mathrm{F}$ atoms are clearly longer than those of other $\mathrm{P}-\mathrm{F}$ bonds (see Table S1, ESI). On the other hand, the P-F bond distances of the $\mathrm{Ni}^{\mathrm{II}}$ analogue are in the range from 1.466 to $1.593 \AA$ and a similar trend to $\alpha \mathbf{- 1}$ is not observed. Hence, it should be noted that the $\mathrm{PF}_{6}{ }^{-}$anions of $\alpha-1$ undoubtedly interact with the $\mathrm{Cu}^{\mathrm{II}}$ ions, which affects the structural distortion from a noncoordinated form.

The complexes I and II alternately stack to form a chain with the distance between $\mathrm{Cu}^{\mathrm{II}}$ atoms being $8.63 \AA$ (Fig. 1b). These chains are packed in a roughly hexagonal fashion, as shown in Fig. 1c. Such a packing structure is similar to that of $\alpha-\left[\mathrm{Ni}(\mathrm{NCS})_{2}(4-\mathrm{mepy})_{4}\right]$. $^{3 \mathrm{e}, 3 \mathrm{i}}$ The overall packing structure of these $\mathrm{Cu}^{\mathrm{II}}$ complexes is too dense to leave vacant space (accessible void space calculated by the PLATON program is $0.6 \%) .^{11}$

In the presence of Lewis-base guests such as acetone and 2-butanone, guest-inclusion complexes of $\gamma$-1 $\supset 2$.5acetone and $\gamma$-1 $\supset 2.25$ (2-butanone) were formed. The structures around the $\mathrm{Cu}^{\mathrm{II}}$ centers are illustrated in Fig. 2a and 2b. In each complex, there are two crystallographically independent $\mathrm{Cu}^{\mathrm{II}}$ complexes (I and II), both of which have different coordination environments, in contrast to $\alpha-\mathbf{1}$. The structures of complex I in $\gamma$-1 $\supset 2.5$ acetone and $\gamma$-1 $\supset 2.25$ (2-butanone) are similar to 
that in $\alpha-1$. The $\mathrm{Cu}^{\mathrm{II}}$ centers of complex II have elongated octahedral environments with four 4-mepy nitrogen atoms in the equatorial plane and one fluorine atom of the $\mathrm{PF}_{6}{ }^{-}$anion and one oxygen atom of acetone or 2-butanone at the axial sites. The $\mathrm{Cu}-\mathrm{O}$ bond distances are 2.427(4) $\AA$ for $\gamma$ $1 \supset 2.5$ acetone and 2.482(2) $\AA$ for $\gamma$-1 $\supset 2.25$ (2-butanone). Each $\mathrm{Cu}^{\mathrm{II}}$ complex assembles to form two-dimensional sheets parallel to the $a b$-plane, as shown in Fig. 2c. These sheets stack along the $c$-axis (Fig. $2 \mathrm{~d}$ ), and uncoordinated $\mathrm{PF}_{6}{ }^{-}$and ketone molecules are included between the sheets. The accessible void space calculated by the PLATON program is 32 and 33\% for $\gamma$-1 $\supset 2.5$ acetone and $\gamma$-1 $\supset 2.25$ (2-butanone), respectively. ${ }^{11}$

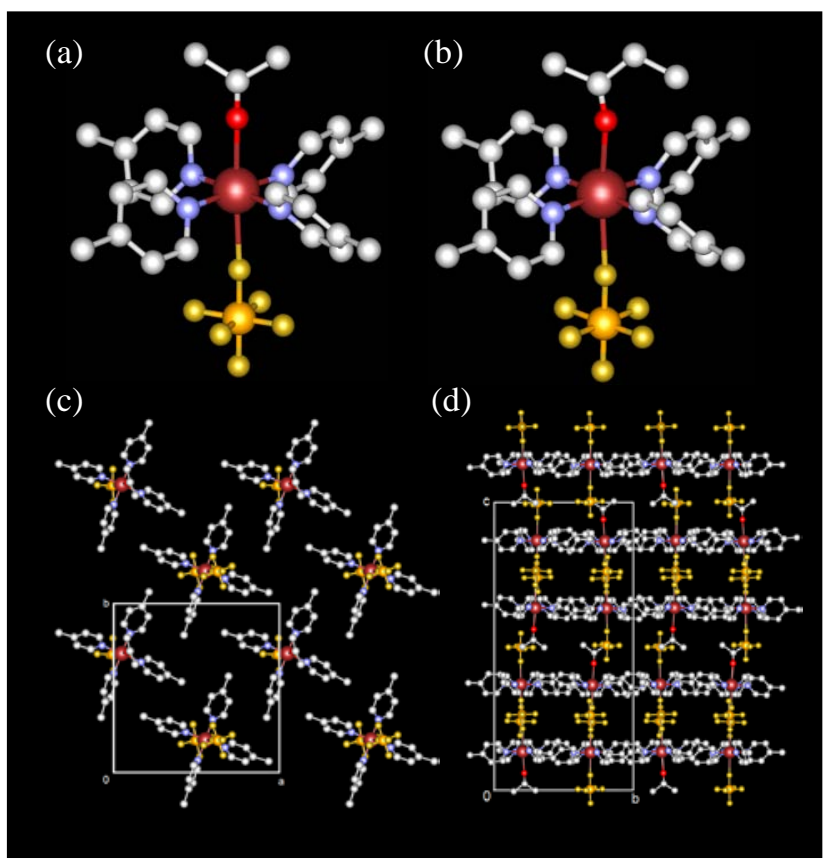

Fig. 2 Crystal structures of $\gamma$-1 $\supset 2$.5acetone and $\gamma$-1 $\supset 2.25$ (2-butanone): (a and b) the molecular structures of $\gamma-\mathbf{1} \supset 2.5$ acetone and $\gamma-1 \supset 2.25(2-$ butanone), (c) the sheet arrangement of $\gamma-\mathbf{1} \supset 2.5$ acetone in the projection along the $c$-axis, and (d) the packing view of $\gamma$-1 $\supset 2$.5acetone in the projection along the $a$-axis. The hydrogen atoms, free $\mathrm{PF}_{6}{ }^{-}$anions, and acetone guests are omitted for clarity.

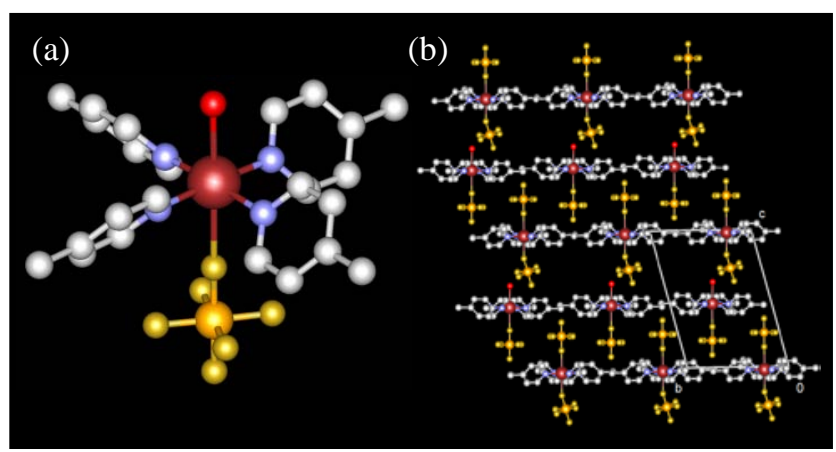

Fig. 3 Crystal structure of $\gamma-1 \supset 0.5 \mathrm{H}_{2} \mathrm{O} \cdot 2$ benzene: (a) the molecular structure and (b) the packing view in the projection along the $a$-axis. The hydrogen atoms, free $\mathrm{PF}_{6}{ }^{-}$anions, and benzene guests are omitted for clarity.

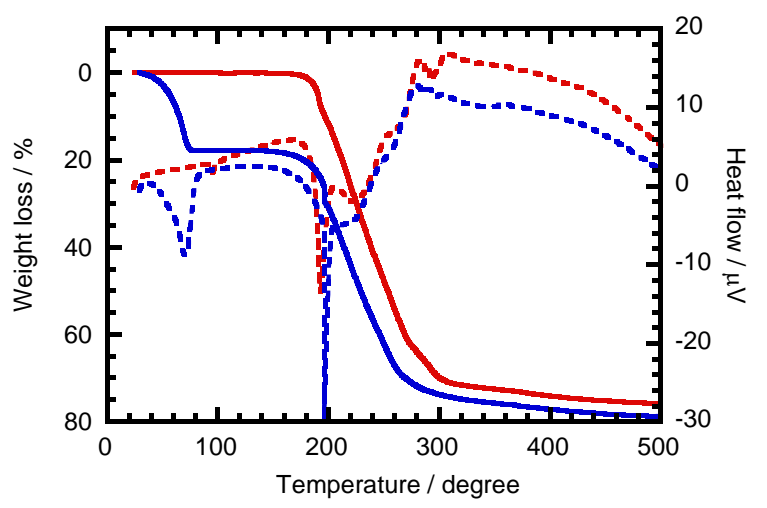

Fig. 4 TGA (solid lines) and DTA (dotted lines) curves of $\alpha-\mathbf{1}$ (red) and $\gamma$-1つ2benzene (blue).

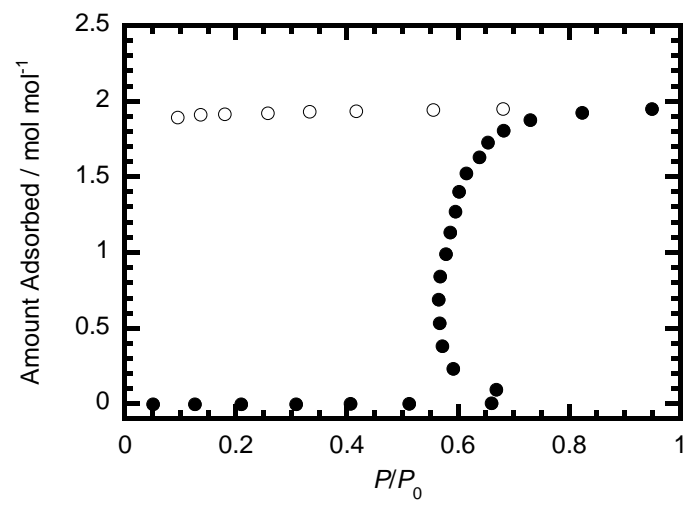

Fig. 5 Adsorption (filled symbols) and desorption (open symbols) isotherms for benzene vapor in $\alpha-1$ at $298 \mathrm{~K}$.

Recrystallization of $\alpha \mathbf{- 1}$ in $\mathrm{CHCl}_{3}$ /benzene produced two kinds of the benzene-inclusion complexes, $\gamma$ $\mathbf{1} \supset 0.5 \mathrm{H}_{2} \mathrm{O} \cdot 2$ benzene and $\gamma$-1 $\supset$ 2benzene. $\gamma$ $1 \supset 0.5 \mathrm{H}_{2} \mathrm{O} \cdot 2$ benzene, which was obtained using nondistilled solvents under the atmosphere, has two crystallographically independent $\mathrm{Cu}^{\mathrm{II}}$ complexes I and II similar to $\gamma$-1 $\supset 2$.5acetone and $\gamma$-1 $\supset 2.25$ (2-butanone). Complex I has a similar coordination environment to $\alpha \mathbf{- 1}$, while complex II has an elongated octahedral environment with four 4-mepy nitrogen atoms in the equatorial plane, and one fluorine atom of the $\mathrm{PF}_{6}{ }^{-}$anion and one oxygen atom of $\mathrm{H}_{2} \mathrm{O}$ at the axial sites (Fig. 3a). The origin of $\mathrm{H}_{2} \mathrm{O}$ may be the solvents used $\left(\mathrm{CHCl}_{3}\right.$ and benzene), neither of which was distilled before use. The assembly state of $\gamma \mathbf{- 1} \supset 0.5 \mathrm{H}_{2} \mathrm{O} \cdot 2$ benzene is similar to those of $\gamma$-1 $\supset 2.5$ acetone and $\gamma$-1 $\supset 2.25$ (2-butanone) (Fig. 3b). Coordination-free $\mathrm{PF}_{6}{ }^{-}$anions and benzene guests are filled into the space formed between the sheets. The accessible void space calculated by the PLATON program is $33 \% .{ }^{11}$ On the other hand, $\gamma$-1 $\supset$ 2benzene was got under a nonaqueous condition. In the crystal, there is single-species $\mathrm{Cu}^{\mathrm{II}}$ complex having the similar coordination environment to $\alpha-\mathbf{1}$. One of two coordinated $\mathrm{PF}_{6}{ }^{-}$anions has the disordered structure (see Fig. S1). The $\mathrm{Cu}-\mathrm{F}$ bond distances (2.501(3), 2.43(2), and 2.544(14) §) are close to those for other complexes presented 
in this paper. It should be noted that $\alpha-\mathbf{1}$ accommodates benzene guests without reconstitution of coordination structures around the $\mathrm{Cu}^{\mathrm{II}}$ ions in the absence of Lewis base guests. The assembly state of $\gamma-\mathbf{1} \supset 2$ benzene is similar to those of other $\gamma$-type complexes (Fig. S1). The accessible void space calculated by the PLATON program is $31 \% .^{11}$

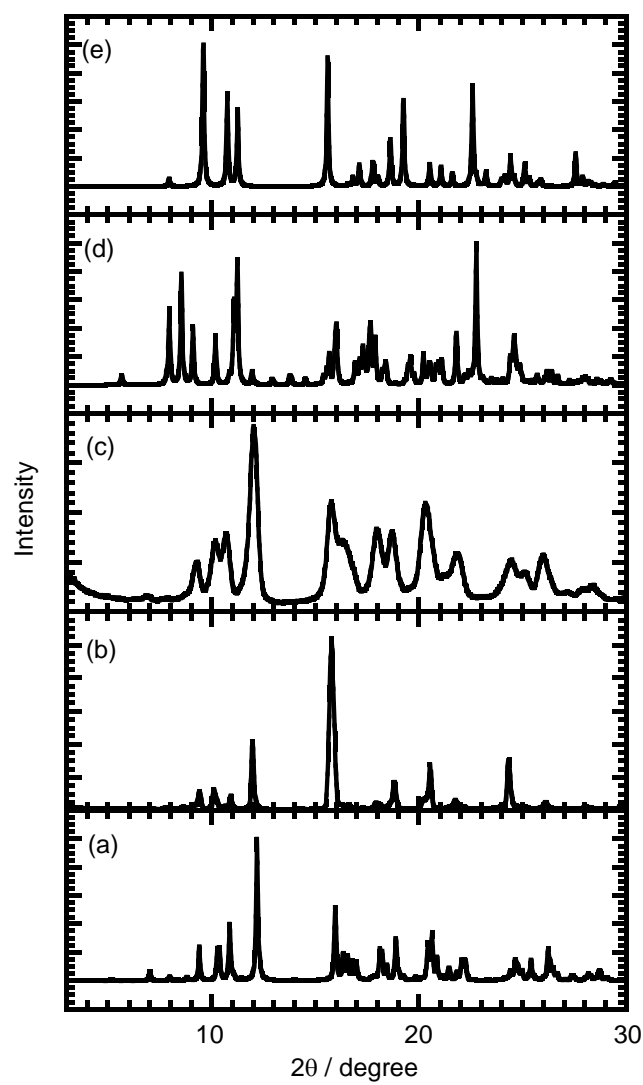

Fig. 6 XRD patterns of (a) simulated $\alpha-1$ from single-crystal analysis, (b) $\alpha-\mathbf{1}$, (c) $\alpha-\mathbf{1}^{\prime}$ obtained by drying $\gamma-\mathbf{1} \supset 2$ benzene in vacuum at room temperature for $2 \mathrm{~h}$, and ( $\mathrm{d}$ and e) simulated $\gamma-\mathbf{1} \supset 0.5 \mathrm{H}_{2} \mathrm{O} \cdot 2$ benzene (d) and $\gamma$-1 $\supset$ 2benzene (e) from single-crystal analysis.

\section{Adsorption properties for benzene vapor}

When $\alpha-1$ was exposed to a benzene vapor for $4 \mathrm{~h}$, a benzeneinclusion complex was formed. The TG-DTA curve (Fig. 4) reveals that the obtained complex has the formula $\left\{\left[\mathrm{Cu}\left(\mathrm{PF}_{6}\right)_{2}\left(4-\right.\right.\right.$ mepy $\left._{4}\right] \cdot$-2benzene $\}$ ( $\gamma$-1 $\supset$ 2benzene $)$, a formula that is consistent with the results of crystal analysis. The adsorption isotherm for benzene in $\alpha-\mathbf{1}$ was measured to elucidate the adsorption phenomenon of benzene. The adsorption isotherm at $298 \mathrm{~K}$ shows a sudden increase at the relative pressure of 0.67 , and attains saturation (Fig. 5). On the other hand, the desorption isotherm is almost flat in the measured pressure range. The saturated amount of benzene is ca. 2 mol per mol of $\mathrm{Cu}^{\mathrm{II}}$ ion, coincident with the value obtained from the TG curve and the crystal analysis. An abrupt increase in adsorption volume and decrease in pressure was observed at a certain pressure. This phenomenon can be explained according to the method of measuring volumetric adsorption and gate-opening adsorption phenomena. ${ }^{12}$ At this pressure, $\alpha-\mathbf{1}$ transforms from a closed to an open structure and suddenly adsorbs some of the vapor in the measurement cell, which results in a loss of pressure. These results indicate that $\alpha-\mathbf{1}$ is converted into $\gamma-\mathbf{1} \supset$ 2benzene with retention of coordination environments around the $\mathrm{Cu}^{\mathrm{II}}$ ions, because of the very weak Lewis-base ability of benzene. We next attempted the formation of empty $\gamma-\mathbf{1}$ by removal of all benzene guests from $\gamma$-1 $\supset$ 2benzene. However, the XRD pattern of the obtained dry compound $\left(\alpha-\mathbf{1}^{\prime}\right)$ shows similar peak positions to those of $\alpha-1$, as shown in Fig. 6b and 6c, suggesting the lability of empty $\gamma \mathbf{- 1}$. A similar trend was observed in the Werner-type $\mathrm{Ni}^{\mathrm{II}}$ complexes. ${ }^{3 \mathrm{i}}$ The XRD peaks of $\alpha-\mathbf{1}^{\prime}$ become much broader than those of $\alpha \mathbf{- 1}$, which is probably attributed to a decrease of crystal size (Fig. S2, ESI). Such a slight change in assembly state strongly affects adsorption properties (vide infra).

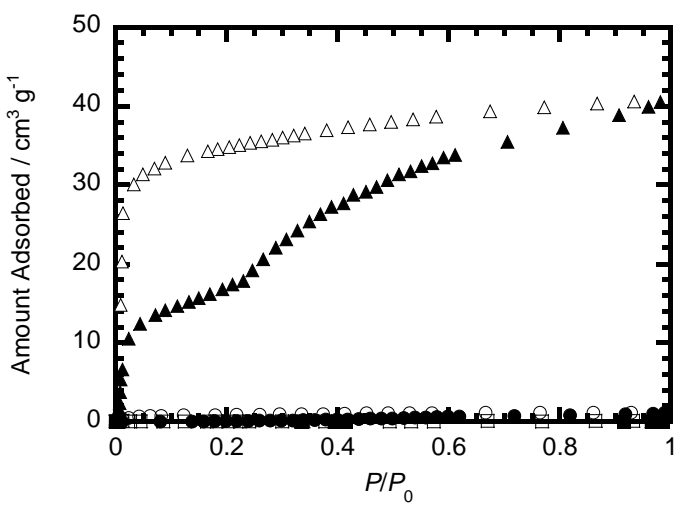

Fig. 7 Adsorption (filled symbols) and desorption (open symbols) isotherms for $\mathrm{CO}_{2}$ gas in $\alpha$-[Ni(NCS) 2 (4-mepy) 4 (circles), $\alpha-1$ (squares), and $\alpha-\mathbf{1}^{\prime}$ (triangles) at $195 \mathrm{~K}$.

\section{Adsorption properties for $\mathrm{CO}_{2}$ gas}

Adsorption and desorption properties of $\alpha-\mathbf{1}$ and $\alpha-\mathbf{1}^{\prime}$ were measured with the Werner-type $\mathrm{Ni}^{\mathrm{II}}$ complex, $\alpha$-[Ni(NCS) $)_{2}(4-$ mepy $)_{4}$ ]. Fig. 7 shows the adsorption/desorption isotherms for $\mathrm{CO}_{2}$ gas at $195 \mathrm{~K}$. In the case of $\alpha-\mathbf{1}$ and $\alpha$-[Ni(NCS) $)_{2}(4-$ mepy) ${ }_{4}$, almost no $\mathrm{CO}_{2}$ gas is adsorbed on these complexes, which is consistent with the fact that their complexes densely pack. Surprisingly, $\alpha-\mathbf{1}^{\prime}$ exhibits an unprecedented adsorption/desorption behavior. Despite $\boldsymbol{\alpha - \mathbf { 1 } ^ { \prime }}$ having the same structure as $\alpha-1$-that is, dense packing $-\mathrm{CO}_{2}$ gas is adsorbed only onto $\alpha-\mathbf{1}^{\prime}$. As shown in Fig. 7 , the adsorption isotherm shows a stepwise curve. First, the isotherm exhibits little increase in the adsorption amount, indicating that the densely packed structure is retained. At the relative pressure of $8 \times 10^{-}$ 3 , the amount adsorbed steeply increases and reaches 17 $\mathrm{cm}^{3} \cdot \mathrm{g}^{-1}$ at the relative pressure of 0.23 , followed by further adsorption. The adsorbed amount at the relative pressure of 0.98 is $41 \mathrm{~cm}^{3} \cdot \mathrm{g}^{-1}$. The desorption isotherm does not trace the adsorption isotherm any more, instead showing an abrupt drop at the relative pressure $\sim 10^{-2}$. From the results of the crystal structure, XRD pattern, and the adsorption isotherm for benzene, it is suggested that $\alpha \mathbf{- 1} \mathbf{1}^{\prime}$ has a nonporous structure. The gate-opening-type adsorption occurs when the assembled 
structure changes during the adsorption process from a closed structure to an open one at a specific pressure. ${ }^{12}$ Hence, the first adsorption step is found to be a gate-opening-type adsorption behavior. By applying the Langmuir model, we found the apparent surface area to be $340 \mathrm{~m}^{2} \cdot \mathrm{g}^{-1}$, supporting the suggestion that the adsorption occurs within the crystals.

Size effects for adsorption properties have been reported in some PCPs. ${ }^{13,14}$ The three-dimensional PCP $\left\{\left[\mathrm{Cr}_{3} \mathrm{FO}(1,4-\right.\right.$ benzenedicarboxylate $\left.\left.)_{3}\left(\mathrm{H}_{2} \mathrm{O}\right)_{2}\right] \cdot \mathrm{xH}_{2} \mathrm{O}\right\}_{n}(\mathrm{MIL}-101)$ has a large free aperture, mesoporous cages, and a record adsorption capacity (Langmuir surface area $~ 5900 \pm 300 \mathrm{~m}^{2} \cdot \mathrm{g}^{-1}$ ). ${ }^{15} \mathrm{MIL}-$ 101 nanocrystals, whose size is smaller than MIL-101 synthesized using conventional hydrothermal techniques, were obtained using a microwave irradiation technique. Such a difference in crystal size only slightly affects the rate of adsorption. $^{13}$ The flexible PCP of [Zn(isophthalate)(4,4'bipyridine $]_{n} \quad$ (CID-1) possesses two-dimensional interdigitated layers and shows drastic structural transformation triggered by guest adsorption and desorption. ${ }^{16}$ PCP nanocrystals of CID-1, which are obtained by the combined technique of nonaqueous inverse microemulsion and ultrasonication, show that the total adsorption amount within nanocrystals is almost the same as for bulk crystals, but the shapes of the adsorption/desorption isotherms differ and the adsorption kinetics increase, compared with bulk crystals. ${ }^{14}$ These changes are mainly attributed to nanocrystal size with shorter diffusion length. $\alpha \mathbf{- 1}$ and $\boldsymbol{\alpha - 1}$ ' are the first example that the decrease in crystal size causes a dramatic increase in adsorption capacity.

Table 1 Adsorption potentials $\left(\mathrm{kJ} \cdot \mathrm{mol}^{-1}\right)$ for the $\left[\mathrm{Cu}\left(\mathrm{PF}_{6}\right)_{2}(4-\mathrm{mepy})_{4}\right]$ and $\left[\mathrm{Ni}(\mathrm{NCS})_{2}(4-\mathrm{mepy})_{4}\right]_{\text {units. }^{a}}$

\begin{tabular}{|c|c|c|c|}
\hline $\begin{array}{l}\mathrm{CO}_{2} \\
\text { Compound }\end{array}$ & & Adsorption potential $^{c}$ & Difference $^{d}$ \\
\hline \multirow[t]{2}{*}[\mathrm{Cu}(\mathrm{PF}_{6})_{2}(4-\text{-mepy})_{4}]{} & I & 15.8 & 1.0 \\
\hline & II & 16.6 & 1.2 \\
\hline \multirow{3}{*}{$\begin{array}{l}{\left[\mathrm{Ni}(\mathrm{NCS})_{2}\left(4-\mathrm{mepy}_{4}\right]\right.} \\
{\left[\mathrm{Cu}(4-\mathrm{mepy})_{4}\right]^{b}}\end{array}$} & & 15.3 & 0.8 \\
\hline & I & 14.8 & \\
\hline & II & 15.4 & \\
\hline \multicolumn{2}{|l|}{$\left[\mathrm{Ni}(4-\mathrm{mepy})_{4}\right]^{b}$} & 14.5 & \\
\hline \multicolumn{4}{|l|}{$\mathrm{N}_{2}$} \\
\hline \multirow{3}{*}{$\begin{array}{l}\text { Compound } \\
{\left[\mathrm{Cu}\left(\mathrm{PF}_{6}\right)_{2}(4-\text {-mepy })_{4}\right]}\end{array}$} & & Adsorption potential $^{c}$ & Difference $^{d}$ \\
\hline & I & 10.1 & 0.6 \\
\hline & II & 10.6 & 0.8 \\
\hline \multicolumn{2}{|l|}{$\left[\mathrm{Ni}(\mathrm{NCS})_{2}\left(4-\mathrm{mepy}_{4}\right]\right.$} & 9.8 & 0.4 \\
\hline \multirow[t]{2}{*}[\mathrm{Cu}(4-\mathrm{mepy})_{4}]{$^{b}$} & I & 9.5 & \\
\hline & II & 9.8 & \\
\hline \multicolumn{2}{|l|}{$\left[\mathrm{Ni}(4-\mathrm{mepy})_{4}\right]^{b}$} & 9.4 & \\
\hline \multicolumn{4}{|c|}{$\begin{array}{l}{ }^{a} \text { The atomic coordinates of } \alpha-1 \text { and } \alpha-\left[\mathrm{Ni}(\mathrm{NCS})_{2}(4-\text { mepy })_{4}\right] \text { were used } \\
\text { for the calculation. In the case of } \alpha-\mathbf{1} \text {, there are two crystallographically } \\
\text { independent units, I and II. }{ }^{b} \text { The anion parts are deleted. }{ }^{c} \text { Maximum } \\
\text { value. }{ }^{d}(\text { Adsorption potential })_{\left[\mathrm{M}(\mathrm{A})_{2}(4-\mathrm{mepy})_{4}\right]}-(\text { Adsorption potential })_{[\mathrm{M}(4-} \\
{\left.\text { mepy } \mathrm{y}_{4}\right]}\left(\mathrm{M}=\mathrm{Cu}^{\mathrm{II}} \text { or } \mathrm{Ni}^{\mathrm{II}}, \mathrm{A}=\mathrm{PF}_{6}{ }^{-} \text {or } \mathrm{NCS}^{-}\right) \text {. }\end{array}$} \\
\hline
\end{tabular}

Previously, we have calculated the natural charges and the electrostatic surface potentials mapped onto a surface of total electron density in the unit of $\alpha-\mathbf{1}$ and $\alpha$-[Ni(NCS $)_{2}$ (4-mepy) $)_{4}$, in which the unit of $\alpha \mathbf{- 1}$ has a more polar structure than that of $\alpha$ - $\left.\left[\mathrm{Ni}(\mathrm{NCS})_{2} \text { (4-mepy) }\right)_{4}\right]$ and the $\mathrm{F}$ atoms of the $\mathrm{PF}_{6}{ }^{-}$anions possess negative charges. These results imply that the $\mathrm{PF}_{6}{ }^{-}$ anions act as electron donors and interact with electronacceptor $\mathrm{CO}_{2}$ molecules. We speculate that the large hysteresis curves observed in $\mathbf{\alpha - \mathbf { 1 } ^ { \prime }}$ are due to the strong hostguest interactions between the $\mathrm{PF}_{6}{ }^{-}$anions and $\mathrm{CO}_{2}$ molecules.

The adsorption potentials around the unit of $\alpha-1$ and $\alpha$ $\left[\mathrm{Ni}(\mathrm{NCS})_{2}(4 \text {-mepy })_{4}\right]$ were calculated by molecular simulation to elucidate the effect of the $\mathrm{PF}_{6}{ }^{-}$anion. As shown in Table 1, the $\mathrm{Cu}^{\mathrm{II}}$ complexes show slightly higher adsorption potentials for $\mathrm{CO}_{2}$ and $\mathrm{N}_{2}$ gases than the $\mathrm{Ni}^{\mathrm{II}}$ complex. Next, to confirm that such an enhancement is attributed to the $\mathrm{PF}_{6}{ }^{-}$anion, the differences between the adsorption potentials in the presence and absence of anions were calculated. As a result, the differences for the $\mathrm{Cu}^{\mathrm{II}}$ complexes are also slightly higher than those for the $\mathrm{Ni}^{\mathrm{II}}$ complexes. Hence, the $\mathrm{PF}_{6}{ }^{-}$anion indeed enhances the adsorption potential, compared with the $\mathrm{NCS}^{-}$anion. In real crystals, a gas molecule is probably incorporated in space surrounded by several discrete complexes, which means that the real adsorption potential is further amplified.

We deduce the reason why the dense $\alpha-\mathbf{1}^{\prime}$ adsorbs $\mathrm{CO}_{2}$ gas from these experimental and calculational results. The crystal size of $\alpha \mathbf{- 1}$ ' is smaller than $\alpha \mathbf{- 1}$, meaning that there are more molecules on the surface of crystals in $\alpha-\mathbf{1}^{\prime}$. The molecules on the surface take a more unstable state than those inside the crystal because of insufficient packing. In addition, the polar $\mathrm{Cu}-\mathrm{PF}_{6}$ units in $\alpha-\mathbf{1}^{\prime}$ enhance the interaction with gas molecules. These factors probably cause flexible adsorption in the dense $\alpha-\mathbf{1}^{\prime}$ form.

\section{Conclusions}

In this paper, we reported the syntheses and adsorption properties of PACs, quasi-Werner-type complexes with flexible and polar $\mathrm{Cu}-\mathrm{PF}_{6}$ bonds. The introduction of such $\mathrm{Cu}-\mathrm{PF}_{6}$ bonds afforded unprecedented guest-inclusion structures and adsorption properties, which have never been observed in traditional Werner-type complexes. Work is now in progress to obtain not only a porous $\beta$ - $\left.\left[\mathrm{Cu}\left(\mathrm{PF}_{6}\right)_{2} \text { (4-mepy }\right)_{4}\right]$ complex with a robust framework, but also other derivatives $\left[\mathrm{Cu}\left(\mathrm{PF}_{6}\right)_{2}(\mathrm{~L})_{4}\right] \quad(\mathrm{L}=$ pyridine derivatives $)$ with unique adsorption properties.

\section{Experimental}

\section{Synthesis}

All chemicals and solvents used during the syntheses were reagent grade. $\alpha-\left[\mathrm{Cu}\left(\mathrm{PF}_{6}\right)_{2}(4-\text {-mepy })_{4}\right](\alpha-\mathbf{1})$ was prepared according to the literature method. ${ }^{7 \mathrm{a}}$

$\left\{\left[\mathrm{Cu}\left(\mathrm{PF}_{6}\right)_{2}(4-\mathrm{mepy})_{4}\right]\left[\mathrm{Cu}\left(\mathrm{PF}_{6}\right)(\mathbf{4}-\right.\right.$

mepy) ${ }_{4}$ (acetone) $] \cdot \mathrm{PF}_{6} \cdot 4$ acetone\}

$\left\{\left[\mathrm{Cu}\left(\mathrm{PF}_{6}\right)_{2}\left(4-\mathrm{mepy}_{4}\right]\left[\mathrm{Cu}\left(\mathrm{PF}_{6}\right)\left(4-\mathrm{mepy}_{4}(2-\right.\right.\right.\right.$

butanone) $] \cdot \mathrm{PF}_{6} \cdot 3.5(2$-butanone $) \quad(\gamma$-1つ2.25(2-butanone) $)$, $\left\{\left[\mathrm{Cu}\left(\mathrm{PF}_{6}\right)_{2}\left(4-\mathrm{mepy}_{4}\right]\left[\mathrm{Cu}\left(\mathrm{PF}_{6}\right)(4-\right.\right.\right.$

mepy $\left.)_{4}\left(\mathrm{H}_{2} \mathrm{O}\right)\right] \cdot \mathrm{PF}_{6} \bullet 4$ benzene $\} \quad\left(\gamma-1 \supset 0.5 \mathrm{H}_{2} \mathrm{O} \cdot 2\right.$ benzene $)$ and $\left\{\left[\mathbf{C u}\left(\mathbf{P F}_{6}\right)_{2}(4-m e p y)_{4}\right] \cdot 2 b e n z e n e\right\} \quad(\gamma-1 \supset 2$ benzene $)$. These complexes were obtained by recrystallization of $\alpha-\mathbf{1}$ in acetone/hexane $\quad(\gamma$-1 $\supset 2.5$ acetone $), \quad$ 2-butanone/hexane $\quad(\gamma$ 1 $\supset 2.25$ (2-butanone), and $\mathrm{CHCl}_{3} /$ benzene $(\gamma$ $1 \supset 0.5 \mathrm{H}_{2} \mathrm{O} \bullet 2$ benzene and $\gamma-\mathbf{1} \supset 2$ benzene). In the case of $\gamma$ - 
1 $\supset$ 2benzene, crystals were obtained using dried solvents under $\mathrm{N}_{2}$ atmosphere.

\section{Physical measurements}

XRD data were collected using a Rigaku RINT-Ultima III diffractometer employing $\mathrm{CuK} \alpha$ radiation. Thermogravimetric analysis (TGA) and differential thermal analysis (DTA) were performed using a Rigaku Thermo Plus 2/TG-DTA8120 over the temperature range 298-773 $\mathrm{K}$ under an $\mathrm{N}_{2}$ atmosphere. The adsorption isotherms for $\mathrm{CO}_{2}$ and benzene at $195 \mathrm{~K}$ and $298 \mathrm{~K}$, respectively, were measured with an automatic volumetric adsorption apparatus (BELSORP MAX; BEL Japan, Inc.). Prior to the adsorption measurements, the sample was treated under reduced pressure $\left(<10^{-2} \mathrm{~Pa}\right)$ at $293 \mathrm{~K}$ for 12 h.

\section{Molecular simulations}

Atomic positions were obtained from the crystallographic structure of PACs, $\alpha-\mathbf{1}^{7 \mathrm{a}}$ and $\alpha$-[Ni(NCS $)_{2}$ (4-mepy) $\left.)_{4}\right]^{3 \mathrm{i}}$ Adsorption potentials were calculated by molecular simulation of PACs using a universal force field. ${ }^{17}$ Intermolecular interaction was evaluated from the combination potential model of Lennard-Jones and Coulomb-type interactions. Effective diameters of $\mathrm{Cu}, \mathrm{Ni}, \mathrm{P}, \mathrm{F}, \mathrm{N}, \mathrm{S}, \mathrm{C}$, and $\mathrm{H}$ are 0.3495 , $0.2834,0.4147,0.3364,0.366,0.4035,0.3851$, and $0.2886 \mathrm{~nm}$, respectively. The potential well depths are 2.5, 7.6, 153.6, 25.2, 34.7, 138.0, 52.9, and $22.2 \mathrm{~K}$, respectively. The electric charges of $\mathrm{Cu}, \mathrm{Ni}, \mathrm{P}, \mathrm{F}$, and $\mathrm{N}$ are $2,2,5,-1$, and -1 , respectively. On the other hand, $\mathrm{C}, \mathrm{S}$, and $\mathrm{H}$ atoms have a zero charge. A unit of coordination complex in a unit cell was used for the calculation without periodic boundary conditions.

\section{Crystallography}

X-ray diffraction measurements on $\gamma$-1 $\supset 2.5$ acetone, $\gamma$ 1つ2.25(2-butanone), $\quad \gamma-\mathbf{1} \supset 0.5 \mathrm{H}_{2} \mathrm{O} \cdot 2$ benzene, and $\gamma$ $1 \supset$ 2benzene, were performed using a Rigaku RAXIS-RAPID imaging plate diffractometer using graphite-monochromated MoK $\alpha$ radiation $(\lambda=0.71073 \AA$ ). The data were corrected for Lorentz and polarization effects. The structures were solved using direct methods (SIR2004 ( $\gamma$-1 $\supset 2.5$ acetone, $\gamma$-1 $\supset 2.25(2-$ butanone), and $\gamma-\mathbf{1} \supset 0.5 \mathrm{H}_{2} \mathrm{O} \cdot 2$ benzene) and SIR2002 ( $\gamma$ 1 $\supset$ 2benzene) $)^{18,19}$ and expanded using Fourier techniques. ${ }^{20}$ The nonhydrogen atoms except for coordination-free guest molecules were refined anisotropically. The carbon and oxygen atoms of coordination-free guest molecules (acetone, 2-butanone, and benzene) were refined isotropically. All of the hydrogen atoms were refined using the riding model. In $\gamma$ 1 $\supset 2.25$ (2-butanone), because some 2-butanone molecules showed the static disorder, some hydrogen atoms were not located. In $\gamma-\mathbf{1} \supset 0.5 \mathrm{H}_{2} \mathrm{O} \cdot 2$ benzene, the hydrogen atoms of the coordinated $\mathrm{H}_{2} \mathrm{O}$ molecule were not located. The refinements were carried out using full-matrix least-squares techniques on $F^{2}$. All calculations were performed using the CrystalStructure crystallographic software package. ${ }^{21}$ In the case of $\gamma$ $1 \supset$ 2benzene, the refinement was performed using SHELXL97. ${ }^{22}$ The crystallographic data in CIF format are available from the Cambridge Crystallographic Data Centre, CCDC reference numbers 789900 ( $\gamma$-1 $\supset 2.5$ acetone $), 789901 \quad(\gamma$ 1 $\supset 2.25$ (2-butanone)), $789902\left(\gamma-\mathbf{1} \supset 0.5 \mathrm{H}_{2} \mathrm{O} \cdot 2\right.$ benzene $)$, and
803508 ( $\gamma$-1 $\supset$ 2benzene).

Crystal data for $\boldsymbol{\gamma}$-1 $\supset$ 2.5acetone. $\mathrm{C}_{63} \mathrm{H}_{86} \mathrm{Cu}_{2} \mathrm{~F}_{24} \mathrm{~N}_{8} \mathrm{O}_{5} \mathrm{P}_{4}, \mathrm{FW}$ $=1742.37$, monoclinic $P 2{ }_{1} / c, T=173 \mathrm{~K}, a=15.8084(10) \AA, b$ $=15.7072(9) \AA, c=33.2060(16) \AA, \beta=102.5296(16)^{\circ}, V=$ 8048.8(8) $\AA^{3}, Z=4, D_{\text {calc }}=1.438 \mathrm{~g} \cdot \mathrm{cm}^{-3}, F_{000}=3576.00$, $2 \theta_{\max }=55.0^{\circ}$. Final $R 1=0.0910(I>2.00 \sigma(I)), w R 2=0.1290$ $(I>2.00 \sigma(I)), \mathrm{GOF}=1.102$ for 961 parameters and a total of 77221 reflections, 18395 unique $\left(R_{\text {int }}=0.073\right) \cdot \mu=7.122 \mathrm{~cm}^{-1}$. $\rho_{\text {max }}=1.20 \mathrm{e} / \AA^{3}$ and $\rho_{\text {min }}=-1.02 \mathrm{e} / \AA^{3}$.

Crystal data for $\boldsymbol{\gamma}$-1 $\supset$ 2.25(2-butanone). $\mathrm{C}_{66} \mathrm{H}_{92} \mathrm{Cu}_{2} \mathrm{~F}_{24} \mathrm{~N}_{8} \mathrm{O}_{4.5} \mathrm{P}_{4}, \mathrm{FW}=1776.45$, monoclinic $P 2_{1} / c, T=$ $173 \mathrm{~K}, a=15.9844(10) \AA, b=15.7733(13) \AA, c=33.098(3)$ $\AA, \beta=102.2421(19)^{\circ}, V=8155.2(10) \AA^{3}, Z=4, D_{\text {calc }}=1.447$ $\mathrm{g} \cdot \mathrm{cm}^{-3}, F_{000}=3656.00,2 \theta_{\max }=55.0^{\circ}$. Final $R 1=0.0998(I>$ $2.00 \sigma(I)), w R 2=0.1633(I>2.00 \sigma(I)), \mathrm{GOF}=1.041$ for 985 parameters and a total of 75460 reflections, 18593 unique $\left(R_{\text {int }}\right.$ $=0.100) \cdot \mu=7.040 \mathrm{~cm}^{-1} \cdot \rho_{\max }=3.90 \mathrm{e} / \AA^{3}$ and $\rho_{\min }=-3.29$ $\mathrm{e} / \AA^{3}$.

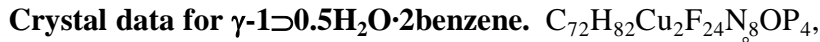
$\mathrm{FW}=1782.44$, triclinic $P 1, T=173 \mathrm{~K}, a=11.3833(6) \AA, b=$ 11.4650(5) $\AA, c=16.2264(8) \AA, \alpha=75.6619(17)^{\circ}, \beta=$ 83.2147(15) ${ }^{\circ}, \gamma=89.1992(14)^{\circ}, V=2037.10(17) \AA^{3}, Z=1$, $D_{\text {calc }}=1.453 \mathrm{~g} \cdot \mathrm{cm}^{-3}, F_{000}=912.00,2 \theta_{\max }=55.0^{\circ}$. Final $R 1=$ $0.0583(I>2.00 \sigma(I)), w R 2=0.1014(I>2.00 \sigma(I))$, GOF $=$ 1.124 for 961 parameters and a total of 19610 reflections, 15173 unique $\left(R_{\text {int }}=0.037\right) \cdot \mu=7.021 \mathrm{~cm}^{-1} \cdot \rho_{\max }=3.01 \mathrm{e} / \AA^{3}$ and $\rho_{\min }=-2.66 \mathrm{e} / \AA^{3}$.

Crystal data for $\boldsymbol{\gamma}$ - $\mathbf{D}$ 2benzene. $\mathrm{C}_{36} \mathrm{H}_{40} \mathrm{Cu}_{1} \mathrm{~F}_{12} \mathrm{~N}_{4} \mathrm{P}_{2}, \mathrm{FW}=$ 882.21, orthorhombic Pnna, $T=173 \mathrm{~K}, a=15.7382(5) \AA ⿻$ 16.4401(6) $\AA, c=15.7189(5) \AA, V=4067.1(3) \AA^{3}, Z=4$, $D_{\text {calc }}=1.441 \mathrm{~g} \cdot \mathrm{cm}^{-3}, F_{000}=1804.00,2 \theta_{\max }=54.9^{\circ}$. Final $R 1=$ $0.0535(I>2.00 \sigma(I)), w R 2=0.1848$ (all reflections), GOF $=$ 1.075 for 255 parameters and a total of 59767 reflections, 4648 unique $\left(R_{\mathrm{int}}=0.055\right) \cdot \mu=7.017 \mathrm{~cm}^{-1} \cdot \rho_{\max }=0.61 \mathrm{e} / \AA^{3}$ and $\rho_{\min }=-0.97 \mathrm{e} / \AA^{3}$.

\section{Acknowledgments}

We thank Prof. H.-C. Chang (Hokkaido University) for allowing the measurements of optical microscope images. This work is supported by a Grant-in-Aid for Scientific Research, Young Scientists (B) (22750114), from MEXT, Japan.

\section{Notes and references}

${ }^{a}$ Research Institute for Electronic Science, Hokkaido University, Sapporo 001-0020, Japan. Fax: 8111706 9420; Tel: 8111706 9418; E-mail: noro@es.hokudai.ac.jp and tnaka@es.hokudai.ac.jp

${ }^{b}$ Graduate School of Environmental Earth Science, Hokkaido University, Sapporo 060-0810, Japan

${ }^{c}$ Graduate School of Science, Chiba University, 1-33 Yayoi, Inage, Chiba 263-8522, Japan

${ }^{d}$ Institute for Multidisciplinary Research for Advanced Materials (IMRAS), Tohoku University, 1-1 Katahira, Aoba-ku, Sendai 980-8577, Japan

$\dagger$ Electronic Supplementary Information (ESI) available: Selected bond distances, crystal structure of $\gamma$-1 $\supset$ 2benzene, morphology of crystals, XRD patterns, adsorption and desorption isotherms for $\mathrm{CO}_{2}$ gas at $195 \mathrm{~K}$ plotted against a logarithmic relative pressure. For ESI, crystallographic data in CIF, and checkcif files, see DOI: 10.1039/b000000x/.

1 (a) O. M. Yaghi, M. O’Keeffe, N. W. Ockwig, H. K. Chae, M. Eddaoudi and J. Kim, Nature, 2003, 423, 705; (b) G. Férey, Chem. Soc. Rev., 2008, 37, 191; (c) S. Kitagawa, R. Kitaura and S. Noro, Angew. Chem., Int. Ed., 2004, 43, 2334; (d) R. E. Morris and P. S. 
Wheatley, Angew. Chem., Int. Ed., 2008, 47, 4966; (e) M. Dincã and J. R. Long, Angew. Chem., Int. Ed., 2008, 47, 6766; (f) S. Ma and H.C. Zhou, Chem. Commun., 2010, 46, 44; (g) U. Mueller, M. Schubert, F. Teich, H. Puetter, K. Schierle-Amdt and J. Pastré, J. Mater. Chem., 2006, 16, 626; (h) C. N. R. Rao, S. Natarajan and R. Vaidhyanathan, Angew. Chem., Int. Ed., 2004, 43, 1466; (i) B. Moulton and M. J. Zaworotko, Chem. Rev., 2001, 101, 1629; (j) S. L. James, Chem. Soc. Rev., 2003, 32, 276; (k) C. Janiak, Dalton. Trans., 2003, 2781; (l) A. J. Black, N. R. Champness, P. Hubberstey, W.-S. Li, M. A. Withersby and M. Schröder, Coord. Chem. Rev., 1999, 183, 117; (m) G. S. Papaefstathiou and MacGillivray, Coord. Chem. Rev., 2003, 246, 169; (n) A. P. Côté and G. K. H. Shimizu, Coord. Chem. Rev., 2003, 245, 49; (o) D. Maspoch, D. Ruiz-Molina and J. Veciana, Chem. Soc. Rev., 2007, 36, 770; (p) D. Bradshaw, J. B. Claridge, E. J. Cussen, T. J. Prior and M. J. Rosseinsky, Acc. Chem. Res., 2005, 38, 273; (q) M. D. Allendorf, C. A. Bauer, R. K. Bhakta and R. J. T. Houk, Chem. Soc. Rev., 2009, 38, 1330; (r) H. Kanoh, A. Kondo, H. Noguchi, H. Kajiro, A. Todoh, Y. Hattori, W.-C. Xu, M. Inoue, T. Sugiura, K. Morita, H. Tanaka, T. Ohba and K. Kaneko, J. Colloid Interface Sci., 2009, 334, 1; (s) S. Takamizawa, Y. Takasaki and R. Miyake, J. Am. Chem. Soc., 2010, 132, 2862; (t) Z. Wang and S. M. Cohen, Chem. Soc. Rev., 2009, 38, 1315; (u) D. Zacher, O. Shekhah, C. Wöll and R. A. Fischer, Chem. Soc. Rev., 2009, 38, 1418, (v) T. Kawamichi, T. Haneda, M. Kawano and M. Fujita, Nature, 2009, 461, 633; (w) S. Noro, S. Kitagawa, T. Akutagawa and T. Nakamura, Prog. Polym. Sci., 2009, 34, 240.

2 (a) D. J. Tranchemontagne, Z. Ni, M. O'Keeffe and O. M. Yaghi, Angew. Chem., Int. Ed., 2008, 47, 5136; (b) M. Fujita, M. Tominaga, A. Hori and B. Therrien, Acc. Chem. Res., 2005, 38, 371; (c) D. Fiedler, D. H. Leung, R. G. Bergman and K. N. Raymond, Acc. Chem. Res., 2005, 38, 351; (d) S. R. Seidel and P. J. Stang, Acc. Chem. Res., 2002, 35, 972; (e) L. Dobrzańska, G. O. Lloyd, H. G. Raubenheimer and L. J. Barbour, J. Am. Chem. Soc., 2005, 127, 13134.

3 (a) W. D. Schaeffer, W. S. Dorsey, D. A. Skinner and C. G. Christian, J. Am. Chem. Soc., 1957, 79, 5870; (b) D. Belitskus, G. A. Jeffrey, R. K. McMullan and N. C. Stephenson, Inorg. Chem., 1963, 2, 873; (c) S. A. Allison and R. M. Barrer, J. Chem. Soc. A, 1969, 1717; (d) D. H. Brown, R. H. Nuttall, J. McAvoy and D. W. A. Sharp, J. Chem. Soc. A, 1966, 892; (e) I. S. Kerr and D. J. Williams, Acta Cryst., 1977, B33, 3589; (f) J. Lipkowski, P. Starzewski and W. Zielenkiewicz, Thermochim. Acta, 1981, 49, 269; (g) A. Y. Manakov and J. Lipkowski, Thermochim. Acta, 1996, 277, 199; (h) A. Y. Manakov, J. Lipkowski and J. Pielaszek, J. Inclusion Phenom., 1999, 35, 531; (i) D. V. Soldatov, G. D. Enright and J. A. Ripmeester, Cryst. Growth Des., 2004, 4, 1185.

4 (a) S. A. Gromilov, I. A. Baydina and G. I. Zharkova, J. Struct. Chem., 1997, 38, 792; (b) D. V. Soldatov, J. A. Ripmeester, S. I. Shergina, I. E. Sokolov, A. S. Zanina, S. A. Gromilov and Y. A. Dyadin, J. Am. Chem. Soc., 1999, 121, 4179; (c) D. V. Soldatov and J. A. Ripmeester, Chem. Mater., 2000, 12, 1827; (d) A. Y. Manakov, D. V. Soldatov, J. A. Ripmeester and J. Lipkowski, J. Phys. Chem. B, 2000, 104, 12111; (e) A. V. Nossov, D. V. Soldatov and J. A. Ripmeester, J. Am. Chem. Soc., 2001, 123, 3563; (f) D. V. Soldatov, E. V. Grachev and J. A. Ripmeester, Cryst. Growth Des., 2002, 2, 401; (g) C. I. Ratcliffe, D. V. Soldatov and J. A. Ripmeester, Microporous Mesoporous Mat., 2004, 73, 71.

5 (a) S. A. Dalrymple and G. K. H. Shimizu, J. Am. Chem. Soc., 2007, 129, 12114; (b) S. A. Dalrymple and G. K. H. Shimizu, Chem. Commun., 2006, 956; (c) S. Takamizawa, T. Akatsuka and T. Ueda, Angew. Chem., Int. Ed., 2008, 47, 1689; (d) S. Takamizawa, M. Kohbara, T. Akatsuka and R. Miyake, New J. Chem., 2008, 32, 1782.

6 S. Noro, Phys. Chem. Chem. Phys., 2010, 12, 2519.

7 (a) S. Noro, D. Tanaka, H. Sakamoto, S. Shimomura, S. Kitagawa, S. Takeda, K. Uemura, H. Kita, T. Akutagawa and T. Nakamura, Chem. Mater., 2009, 21, 3346; (b) S. Noro, T. Akutagawa and T. Nakamura, Chem. Commun., 2010, 46, 3134.

8 R. M. Morrison and R. C. Thompson, Can J. Chem., 1982, 60, 1048.

9 R. M. Morrison, R. C. Thompson and J. Trotter, Can. J. Chem., 1980, 58, 238.
10 S. Noro, N. Yanai, S. Kitagawa, T. Akutagawa and T. Nakamura, Inorg. Chem., 2008, 47, 7360.

11 The accessible void space was calculated after removal of all guest molecules (coordinated, hydrogen-bonding, and free ones) with the program PLATON by using a probe with a radius of $1.2 \AA$ : A. L. Spek, J. Appl. Crystallogr., 2003, 36, 7.

12 (a) A. Kondo, H. Noguchi, S. Ohnishi, H. Kajiro, A. Tohdoh, Y. Hattori, W.-C. Xu, H. Tanaka, H. Kanoh and K. Kaneko, Nano Lett., 2006, 6, 2581; (b) R. Kitaura, K. Seki, G. Akiyama and S. Kitagawa, Angew. Chem., Int. Ed., 2003, 42, 428; (c) D. Tanaka, K. Nakagawa, M. Higuchi, S. Horike, Y. Kubota, T. C. Kobayashi, M. Takata and S. Kitagawa, Angew. Chem., Int. Ed., 2008, 47, 3914; (d) S. Bourrelly, P. L. Llewellyn, C. Serre, F. Millange, T. Loiseau and G. Férey, J. Am. Chem. Soc., 2005, 127, 13519; (e) F.-X. Coudert, M. Jeffroy, A. H. Fuchs, A. Koutin and C. Mellot-Draznieks, J. Am. Chem. Soc., 2008, 130, 14294.

13 S. H. Jhung, J.-H. Lee, J. W. Yoon, C. Serre, G. Férey, J.-S. Chang, Adv. Mater., 2007, 19, 121.

14 D. Tanaka, A. Henke, K. Albrecht, M. Moeller, K. Nakagawa, S. Kitagawa, J. Groll, Nature Chem., 2010, 2, 410.

15 G. Férey, C. Mellot-Draznieks, C. Serre, F. Millange, J. Dutour, S. Surblé, I. Margiolaki, Science, 2005, 309, 2040.

16 S. Horike, D. Tanaka, K. Nakagawa, S. Kitagawa, Chem. Commun., 2007, 3395.

17 A. K. Rappé, C. J. Casewit, K. S. Colwell, W. A. Goddard III and W. M. Skiff, J. Am. Chem. Soc., 1992, 114, 10024.

18 M. C. Burla, R. Caliandro, M. Camalli, B. Carrozzini, G. L. Cascarano, L. De Caro, C. Giacovazzo, G. Polidori and R. Spagna, SIR2004; Istituto di Cristallografia: Bari, Italy, 2005.

19 SIR2002: M. C. Burla, M. Camalli, B. Carrozzini, G. L. Cascarano, C. Giacovazzo, G. Polidori and R. Spagna, J. Appl. Crystallogr., 2003, 36, 1103.

20 P. T. Beurskens, G. Admiraal, G. Beurskens, W. P. Bosman, R. de Gelder, R. Israel and J. M. M. Smits and C. Smykalla, PATTY: DIRDIF-99 Program System, Technical Report of the Crystallography Laboratory; University of Nijmegen: Nijmegen, The Netherlands, 1992.

21 CrystalStructure 3.8: Crystal Structure Analysis Package; Rigaku and Rigaku Americas: The Woodlands, Tx, 2000-2007.

22 G. M. Sheldrick, SHELXL-97: Program for the Refinement of Crystal Structure, University of Göttingen, Germany, 1997. 